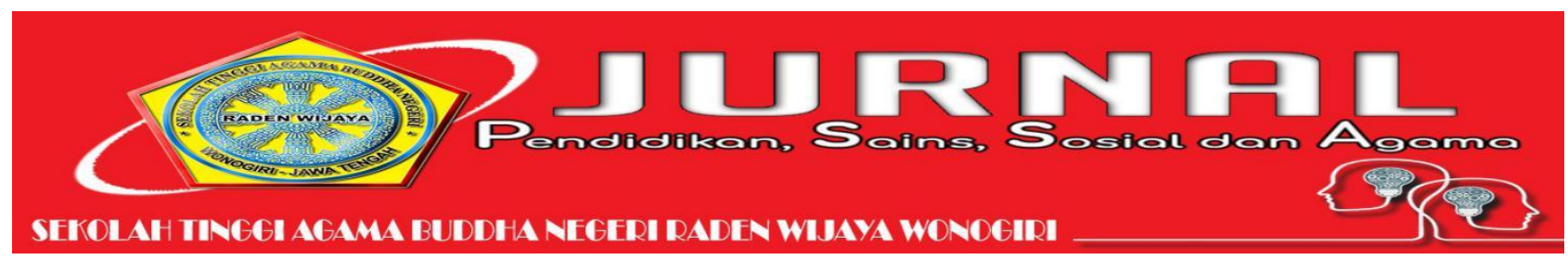

\title{
PERAN KYAI DALAM MEMBINA AKHLAK SANTRI DI PONDOK PESANTREN DARUL ULUM AL-MUMINAH DESA SIMPANG KECAMATAN WANAYASA
}

\author{
Imam Tabroni $^{1}$, Asep Saepul Malik ${ }^{2}$, Diaz Budiarti ${ }^{3}$ \\ Pascasarjana Pendidikan Agama Islam STAI Dr. KH. EZ. Muttaqien Purwakarta \\ imamtabroni70@gmail.com,asepsaepul1705@gmail.com,budiartidiaz@gmail.com
}

\begin{abstract}
Abstrak
Pondok Pesantren sebagai lembaga pendidikan berperan penting dalam membina akhlak santri. Kyai mempunyai kewajiban membina santri agar memiliki akhlak baik di Pondok Pesantren Darul Ulum Al-Muinah. Tujuan penelitian untuk menemukan program Kyai dalam membina akhlak santri. Penelitian menggunakan pendekatan penelitian kualitatif dengan desain fenomenologi. Penelitian fokus pada Kyai dan santri untuk mengetahui peran Kyai dalam membina akhlak santri di Pondok Pesantren tersebut. Langkah-langkah pengumpulan data melalui observasi, wawancara, dan dokumentasi. Analisa dengan reduksi data, display data, dan verifikasi data. Hasil penelitian: (1). Program Kyai di Pondok Pesantren Darul Ulum Al-Muinah meliputi program harian, mingguan dan bulanan. (2). Kyai mampu membina khlak santri meskipun belum seluruhnya, (3). Metode pembinaan Kyai: Metode ceramah, suri teladan dan life skill. (4). Faktor pendukung ditemukan bahwa lokasi Pondok Pesantren strategis, tingginya dukungan alumni, pendidik profesional, dan dukungan dari seluruh pihak. Faktor penghambat ditemukan Pondok Pesantren belum memiliki pengelolaan yang baik dan minimnya sumber pendanaan (5). Kyai selalu membina dan membimbing santri, bermusyawarah bersama pengurus, menganalisa setiap masalah sekaligus memeberi solusinya. Dukungan dapat ditingkatkan dengan memperbaiki pengelolaan dan bermitra dengan semua pihak.
\end{abstract}

Kata kunci: Kyai, pembinaan, akhlak.

\begin{abstract}
Islamic boarding schools as educational institutions play an important role in fostering the morals of students. Kyai has the obligation to foster students to have good morals at the Darul Ulum Al-Muinah Islamic Boarding School. The purpose of the study was to find the Kyai program in fostering the morals of students. The study used a qualitative research approach with a phenomenological design. The research focuses on Kyai and santri to find out the role of Kyai in fostering the morals of students at the Islamic Boarding School. The steps of data collection are through observation, interviews, and documentation. Analysis with data reduction, data display, and data verification. Research results: (1). The Kyai program at Darul Ulum Al-Muinah Islamic Boarding School includes daily, weekly and monthly programs. (2). Kyai is able to foster the character of students, although not entirely, (3). Kyai coaching methods: Lecture method, role model and life skills. (4). Supporting factors were found that the location of the Islamic Boarding School was strategic, the high support from alumni, professional educators, and support from all parties. The inhibiting factors were found that Islamic boarding schools did not have good management and lack of funding sources (5). Kyai always fosters and guides students, consults with the management, analyzes every problem as well as provides a solution. Support can be increased by improving management and partnering with all parties..
\end{abstract}

Keywords: Kyai, coaching, morals.. 


\section{PENDAHULUAN}

Era globalisasi yang merubah tatanan kehidupan secara cepat menyeluruh hanya dalam hitungan waktu. Menjadikan dunia ini sangat sempit, sehingga tak ada lagi jarak antar negara untuk saling berkomunikasi. Semua hal bisa saja diketahui secara terbuka. Fenomena, berita, dan peristiwa bisa didapatkan dengan mudah. Globalisasi membuka ruang yang tidak terbatas dan dapat mempengaruhi perilaku manusia. ${ }^{1}$

Dampak gobalisasi mengarah pada krisis moral yang tidak terbendung saat ini. Pergaulan bebas, tawuran antar remaja, pemakaian NAPZA, dan perilaku seks bebas merupakan beberapa contoh dampak globlisasi. Rentetan peristiwa di atas semakin mengukuhkan bahwa akhlak peserta didik dipengaruhi oleh globalisasi dan pemahaman keagamaan yang kurang. ${ }^{2}$ Generasi muda yang diharapkan menjadi pioner bangsa ke depan, malah direduksi dengan sikap-sikap amoral yang tidak semestinya dilakukan oleh mereka. Nilai-nilai spiritual disinyalir menjadi salah satu faktor fenomena di atas.

Melihat kondisi moral saat ini yang jauh dari nilai-nilai agama ditandai dengan perilaku buruk peserta didik yang diperlihatkan, maka dari itu Pondok Pesantren bisa menjadi pusat pendidikan yang dapat membangun karakter yang baik. Pondok Pesantren mampu mengubah kepribadian dan karakter santriwan dan santriwati untuk menjadi orang yang berguna di masa depan. Kyai sebagai pemimpin sekaligus pengasuh bagi santri dalam kegiatan sehari-hari. Proses pendidikan yang berlangsung dua puluh empat jam yang dilaksanakan di Pondok Pesantren tak lain untuk membina akhlak santri agar menjadi manusia berguna bagi nusa bangsa dan negara. Oleh sebab itu, Pondok Pesantren memiliki beban yang berat

\footnotetext{
${ }^{1}$ Aim Abdulkarim, Pendidikan Kewarganegaraan "Membangun Warga Negara yang Demokratis,"

2 Siti Masitoh, Sofia Gussevi, and Imam Tabroni,

"Peran Wanita Karir Dalam Pendidikan Anak,"

Paedagogie: Jurnal Pendidikan dan studi Islam 2, no. 02 (2021): 109-123, http://e-

jurnal.staimuttaqien.ac.id/index.php/paedagogie/artic le/view/131.
}

Asosiasi Dosen \& Unit Penelitian dan Pengabdian Masyarakat untuk menciptakan generasi-generasi muda yang menjadi harapan orangtuanya kelak.

Akhlak menjadi aspek mendasar pada diri manusia, tanpa akhlak manusia bisa saja seperti hewan yang tak memiliki nilai-nilai kemanusian. Oleh sebab itu, Rasulullah Saw hadir ke dunia ini tak lain hanya untuk memperbaiki akhlak manusia. Akhlak sebagai tolak ukur untuk menempatkan manusia pada derajat yang paling tinggi. ${ }^{3}$ Seberapa besar ilmu pengetahuan seseorang tanpa didasari dengan akhlak, maka tidak ada apa - apanya. Membina akhlak memang sangatlah sulit, tidak semudah membalikan kedua telapak tangan. Proses mendidik, membina dan melatihnya diperlukan uapaya yang optimal. Tumbuhnya akhlak yang baik tentu menjadi dambaan bagi setiap manusia, karna sikap yang baik adalah cerminan sebagaimana di contohkan oleh Nabi Muhammad SAW, beliau tidak pernah menyuruh sesuatu hal tanpa ia sendiri mencontohkannya kepada para sahabatnya. Artinya, tidak sekedar berbicara, tetapi mampu mengimplementasikannya dalam kehidupan sehari-hari.

Salah satu kunci suksesnya pendidikan terletak pada guru atau al-ustadz, mereka memiliki peranan penting dalam mendidikan dan membina akhlak peserta didik dimanapun itu, baik sekolah formal, in formal, non formal dan sebagainya. Jika berbicara peran, maka kita harus mengetahui terlebih dahulu makna dan arti dari peranan itu sendiri. Kita tidak akan bisa mengetahui tanpa mengkaji apa makna dari peran tersebut.

Pengertian kyai dalam konteks Indonesia modern telah mengalami transformasi makna, yakni diberikan kepada pendiri dan pemimpin sebuah Pondok Pesantren yang membaktikan hidupnya demi Allah serta menyebarluaskan dan memperdalam ajaran-ajaran dan pandangan Islam melalui kegiatan pendidikan. ${ }^{4}$ Kyai adalah orang yang memiliki ilmu agama

\footnotetext{
${ }^{3}$ Thomas Lickona, Educating for Character: How Our Schools Can Teach Respect and Responsibility (New York, Canada: Bantam Books, 1991).

${ }^{4}$ Edi Susanto, "Kepemimpinan (Kharismatik) Kyai dalam Perspektif Masyarakat Madura," Karsa 1: 33.
} 
Islam plus amal dan akhlak yang sesuai dengan ilmunya.

Menurut Lubis, Kyai adalah tokoh sentral dalam suatu Pondok Pesantren, maju mundurnya Pondok Pesantren ditentukan oleh wibawa dan kharisma sang kyai di salah satu Pondok Pesantren wafat, maka jelas pamor Pondok Pesantren tersebut akan merosot karena kyai yang menggantikannya tak sepopuler kyai yang telah wafat. ${ }^{5}$

Menurut Suhardono peran dapat di artikan suatu patokan atau ukuran yang terdapat dalam kehidupan manusia sehingga berfungsi untuk dapat membatasi perilaku dalam tiap - tiap posisi, sedangkan menurut Soekanto definisi peran dikaitkan pada pekerjaan yang dilaksanakan secara dinamis sesuai dengan status, kedudukan yang dimilikinya. ${ }^{6}$

Peranan kyai dalam Pondok Pesantren, masyarakat dan santri adalah sebagai berikut :

a. Guru Ngaji

Kyai sebagai guru ngaji dijabarkan secara khusus dalam jabatan-jabatannya diantarnya Sebagai berikut :

Mubaligh, khotib, penasihat, guru Diniyah atau pengasuh dan Qori kitab salaf dalam sistem sorogan. Menurut Zamksari Dhofier dalam menjabarkan tugas kyai dapat dikategorikan kedalam dua bagian yaitu: sorogan dan weton (bandongan). Pertama, sorogan (individu), dan kedua, metode bandongan (balaghan).

b. Tabib (Penjampi)

Kyai memiliki tugas sebagai tabib yang di uraikan dalam bentuk berikut: Kyai melakukan pengobatan dengan rukyah (mengobati pasien dengan doa), mengobati pasien dengan menggunakan alat non medis seperti air, akik dan lainnya dengan perantara kepada sang illahi untuk mengurus roh halus.

c. Rois atau Imam

Sebagai rois atau imam tugas kyai tercermin sebagai berikut : imam sholat

\footnotetext{
${ }^{5}$ Saiful Akhyar Lubis, Konseling Islam Kyai Dan Pondok Pesantren (Yogyakarta: eLSAQ Press, 2007).

${ }^{6}$ Soekanto, Patologi Sosial (Jakarta: Rineka Cipta, 1986).
}

Asosiasi Dosen \& Unit Penelitian dan Pengabdian Masyarakat rawatib dan shalat Sunnah lainnya, imam ritual slametan, imam tahlilan dan imam prosesi perawatan dan penyampaian maksud atau hajatan.

d. Pegawai Pemerintahan

Tugas kyai sebagai pegawai pemerintah tercermin dalam tugas-tugasnya sebagai berikut : Kepala KUA atau penghulu, Moddin, PPN, Guru Agama Islam, pegawai dinas partai politik, dan pengurus organisasi kemasyarakatan.

e. Pengasuh dan Pembimbing Santri

Bentuk Pondok Pesantren yang bermacam-macam adalah pantulan dari seseorang kyai. Kyai memiliki sebutan yang berbeda-beda tergantung daerah tempat tinggalnya. Di Jawa disebut Kyai, di Sunda di sebut Ajengan, di Aceh disebut Tengku, di Sumatera di sebut Syaikh, di Minangkabau disebut Buya di Nusa Tenggara di sebut Tuan Guru. Mereka juga bisa disebut sebagai ulama sebagai sebutan yang lebih umum, walau pemahaman ulama mengalami pergeseran. Kyai disebut alim bila ia benar-benar memahami, mengamalkan dan menfatwakan kitab kuning. Kyai demikian ini menjadi menjadi panutan bagi Pondok Pesantren, bahkan bagi masyarakat Islam secara luas. Namun, didalam konteks kelangsungan Pondok Pesantren kyai dapat dilihat dari perspektif lainnya.

f. Pemimpin Non Formal dan Pemimpin Spiritual.

Kedudukan kyai pasti sangat dekat dengan kelompok-kelompok masyarakat lapisan bawah di desa. Sebagai pemimpin masyarakat, kyai memiliki jama'ah komunitas dan masa yang diikat oleh hubungan keguyuban dan ikatan budaya paternalistik. Petuah-petuahnya selalu didengar, diikuti dan dilaksanakan oleh jama'ah, komunitas dan masa yang dipimpinnya. Maka sudah pasti kyai menjadi seseorang yang ditirukan oleh masyarakat, atau menjadi bapak masyarakat terutama masyarakat desa.

g. Penggerak Kebangkitan Agama

Menurut Kontowijaya bahwa
kebangkitan agama dalam bentuk 
pembenahan lembaga pendidikan Pondok Pesantren dan tarekat Islam pada abad ke-19, dipimpin oleh kyai. Melalui tarekat, pengaruh kyai makin menemukan momentum untuk berkembang makin luas. Bahkan kyai dianggap keramat, yaitu orang yang layak membimbing jama'ah melakukan konsentrasi bertaqorub kepada Allah, sehingga ia dikeramatkan. Tindakan kyai dalam membina anggota baru dalam tarekat benar-benar eksklusif dan menunjukan kekeramatannya sehingga mereka harus taat sepenuhnya tanpa adanya kritik sama sekali.

h. Pemegang Kekuasaan Tertinggi

Peran kyai dalam pendidikan Pondok Pesantren adalah sebagai pemegang kekuasaan tertinggi yang sifatnya absolut, sehingga dalam seluruh kegiatan yang ada di Pondok Pesantren haruslah atas persetujuan kyai. Bahkan dalam proses pentransformasian ilmu pun yang berhak menentukan adalah kyai. Ini terlihat dalam penentuan buku yang dipelajari, materi yang dibahas dan lama waktu yang dibutuhkan dalam mempelajari sebuah buku, kurikulum yang digunakan, penentuan evaluasi, dan tata tertib yang secara keseluruhan di rancang oleh kyai. Keabsolutan ini juga dipengaruhi oleh tingginya penguasaan kyai terhadap tingginya disiplin ilmu tertentu akan mempengaruhi system pendidikan yang digunakan dalam sebuah Pondok Pesantren. Sehingga ada beberapa kyai yang mengharamkan pelajaran umum diajarkan diPondok Pesantren karena adanya pengaruh yang kuat terhadap cara berpikir dan pandangan hidup kyai.

Melihat kajian diatas, peran kyai sangatlah penting dalam membina akhlak santri agar memilik akhlakul kharimah, berilmu, memiliki kemandirian, agar sikapnya mencerminkan keperibadian seorang muslim dan muslimah. Begitupun dengan Nabi Muhammad SAW, beliau di utus ke dunia ini tak lain hanya untuk menyempurnakan akhlak manusia. Dan ini di jelaskan dalam sebuah ayat: "Sesungguhnya telah ada pada diri rasulullah saw suri teladan yang baik bagimu Asosiasi Dosen \& Unit Penelitian dan Pengabdian Masyarakat yaitu bagi orang-orang yang mengharapkan rahmat Allah dan kedatangan hari kiamat dan dia banyak menyebut Allah".

Hal ini pun dijelaskan pula dalam hadits yang diriwayatkan oleh Abi dzar RA yang menyatakan bahwa diutusnya Nabi Muhammad Saw hanya untuk memperbaiki akhlak manusia. $^{7}$

Akhlak menjadi aspek mendasar pada diri manusia, tanpa akhlak manusia bisa saja seperti hewan yang tak memiliki nilai-nilai kemanusian. Oleh sebab itu, rasulullah hadir ke dunia ini tak lain hanya untuk memperbaiki akhlak manusia. ${ }^{8}$

Penelitian yang dilakukan oleh Syamli dan Firdaus pada jurnal JPIK (2018) dengan judul "'Strategi Kyai dalam Pembinaan dan Pembentukan Moral Santri di Ma'had Tahfidz al-Qur'an Zainul Ibad Prenduan', yang menyimpulkan bahwa strategi Kyai dalam membina dan membentuk moral santri memang benar ada peranannya, yang dikarenakan adanya kerjasama antara kyai dan jajaran guru serta kerjasama kyai dengan orangtuanya masing-masing, bahkan kerjasamanya masyarakat setempat. Strategi yang digunakan terbagi menjadi dua yakni strategi reinforcement dan tajribah (pembiasan). ${ }^{9}$

\section{METODE}

Pendekatan yang digunakan ialah kualitatif dengan desain fenomenologi. Ciri penelitian ini ialah mengakaji kehidupan berdasarkan tema dan menggali informasi secara mendalam yang terjadi dilapangan berdasarkan pengalaman Kyai dalam membina akhlak santri di Pondok Pesantren tersebut.

Teknik pengumpulan data menggunakan Observasi mendalam, wawancara, dan studi dokumentasi. Analisis data dengan triangulasi.

\footnotetext{
${ }^{7}$ Firman Ariyana, "Peran Kyai Dalam Membina Akhlak Santri Di Pondok Pesantren Walisongo Kotabumi Lampung" (IAIN Raden Intan Lampung, 2017).

${ }^{8}$ Imam Tabroni, MODEL PENDIDIKAN ISLAM: Teknik Mendidik Anak Dengan Treatment Di Era 4.0 (Bandung: CV Cendekia Press, 2019).

${ }^{9}$ Syamli and Firdaus, "Startegi Kyai Dalam Pembinaan Dan Pembentukan Moral Santri Di Ma'had Tahfidz AlQur'an Zainul Ibad Prenduan," JPIK 1 (2018): 34.
} 
Nara sumber merupakan unsur dari Pondok Pesantren yang meliputi:

a. Pimpinan Pondok Pesantren Darul Ulum Al-Muinah

b. Keluarga Kyai; putra pimpinan Pondok Pesantren Darul Ulum Al-Muinah

c. Para pengurus Pondok Pesantren Darul Ulum Al-Muinah

d. Ustadz di Pondok Pesantren Darul Ulum Al-Muinah

e. Santri dan santriwati Pondok Pesantren Darul Ulum Al-Muinah

f. Masyarakat lingkungan Pondok Pesantren Darul Ulum Al-Muinah

Analisa data menggunkan teknik reduksi data (data reduction), penyajian data (data display), dan penarikan kesimpulan (conclusion drawing/verification).

Uji keabsahan data dilakukan oleh peneliti dengan berbagai tahapan yakni, perpanjangan pengamatan, peningkatan ketekunan, triangulasi, diskusi dengan teman sejawat, analisis kasus negatif dan memberi check.

\section{HASIL DAN PEMBAHASAN}

Pelaksanaan kegiatan pembinaan akhlak di Pondok Pesantren al-Muinah tentunya meruju pada program yang dibuat oleh pihak Pondok Pesantren itu sendiri. Santri diatur mulai bangun tidur sampai tidur kembali. Mereka dikontrol secara intensif oleh pengurus yang telah ditugaskan untuk membina para santri. Meskipun Pondok Pesantren masih terbilang sederhana, namun tata tertib dibuat dan disepakati bersama untuk membina kehidupan santri di Pondok Pesantren.

Pembelajaran santri diarahkan semaksimal mungkin oleh Kyai agar cakap dan mahir al-Qur'an dan kitab kuning. Kyai selalu membimbing, mengawasi, dan meningkatkan kemampuan hafalan al-Qur'an dan pemahaman kitab yang diajarkan.

Selain itu, pada saat melaksanakan programnya Kyai melibatkan pengurus, ustadz, dan santri senior untuk ikut terlibat langusng dalam membina dan membimbing santri agar memiliki keterampilan tertentu, seperti hafalan al-Qur’an, pemahaman kitab, ceramah keagamaan, marawis, dan keterampilan lainnya.

Asosiasi Dosen \& Unit Penelitian dan Pengabdian Masyarakat
Kyai selalu menekankan perilaku contoh santri senior kepada santri junior. Peniruan (imitation) santri junior sangat cepat tanpa memilah dan memilih perilaku mana yang patut dicontoh dan yang harus dijauhi. Oleh karena itu, keterlibatan santri senior untuk membantu Kyai dalam mengembang amanat yang mulia tersebut sangat penting. Klasifikasi santri tersebut bersinggungan dengan istilah yang belaku di Pondok Pesantren, yaitu santri baru dan santri lama. Penjelasannya sebagaimana berikut:

\section{a. Santri Baru}

Santri baru merupakan santri yang mondok di Pondok Pesantren dengan tenggang waktu yang belum lama. Santri tersebut masih perlu beradaptasi dengan lingkungan Pondok Pesantren, transisi antara tempat tinggal dan Pondok Pesantren memang diperlukan waktu yang cukup lama agar para santri dapat merasakan manis dan pahit belajar di Pondok Pesantren yang kental dengan nilai-nilai religius, salah satunya adalah Pondok Pesantren Al-Muinah.

Santri baru membutuhkan bimbingan dan pengajaran yang intens dari para pengasuh disana, mengingat tak selamanya mondok bagi santri baru menjadi kebanggaan, karena kehidupan di Pondok Pesantren memiliki aturan yang telah ditetapkan, jadi tidak bisa bebas begitu saja.

Terkadang ada saja santri baru yang baru mondok tetapi sudah minta di pulangkan lagi, bahkan yang lebih ironi santri tersebut diam-diam tanpa izin pergi meninggalkan pondok untuk pulang tanpa kembali lagi ke Pondok Pesantren. Oleh karena, sistem controling sangat diperhatikan di sini, santri baru dipantau lebih intens oleh para roisnya.

Kemudian, pelaksanaan program pembelajaran yang dilakukan kepada santri baru ini dipegang oleh beberapa santri senior yang telah mendapat mandat dari Pimpinan pondok. Pada dasarnya santri yang lama di amanahkan kembali agar mengamalkan ilmu nya kepada santri yang baru. Hal ini dilakukan agar keilmuwan yang didapat oleh santri lama tidak cepat hilang.

Nasihat Edi Kyai: 'Ketika ilmu di amalkan maka, ilmu yang sudah didapat 
diPondok Pesantren akan semakin bertambah dan berkah (baik). Berbeda dengan keilmuwan yang dipendam, maka ilmu tersebut akan lupa tanpa bekas (seperti air di atas daun talas, tidak berbekas)". Maka, mengamalkan kembali akan menjadi buah dari ilmu itu sendiri. Banyak diantara santri-santri yang mahir pada saat Pondok Pesantren, pandai baca kitab kuningnya, tetapi setelah itu hilang begitu saja karena tidak diamalkan oleh si santri.

\section{b. Santri Lama}

Santri lama memiliki sebutan santri yang sudah bermukim bertahun-tahun lamanya. Keilmuwan yang dimiliki pun cukup matang serta sudah disiapkan untuk terjun ke masyarakat diakhir nanti setelah dselesai mondok oleh Kyai. Santri lama dianggap sudah mampu beradaptasi sepenuhnya dengan dunia Pondok Pesantren, sudah bisa menyesuaikan dengan lingkungannya dari lika-liku dunia Pondok Pesantren.

Kemudian, keilmuwan didapatkan terbilang sudah cakap serta siap digunakan kapan pun dimasyarakat nanti. Lalu, untuk pelaksanaan pembelajaran bagi santri lama di Pondok Pesantren Darul Ulum AlMuinah yakni diajarkan langsung oleh sesepuh pondok yakni oleh Kyai sebagai pimpinan Pondok Pesantren Darul Ulum Al-Muinah .

Proses pembelajaran pun tidak lagi banyak menggunakan metode sorogan, namun yang digunakan adalah metode balagan yang dimana santri menuliskan rumus (ngalogat) pada kitab yang sedang di baca agar nanti para santri setelah selesai melaksanakan balagan mampu membacanya sendiri. Akan tetapi tidak cukup dengan memberikan rumus/ symbol pada kitab itu sendiri, kemampuan nahwu dan shorof pun wajib dimiliki oleh santri santri secara matang agar tidak kebingungan dalam membaca dan menelaah kitab-kitab yang ada.

Ketika para santri sudah menguasai ilmu nahwu dan shorof maka itu bisa mempermudah mereka untuk membaca dan mengkaji berbagai kitab yang ada. Karena dalam membaca kitab kuning kuncinya adalah menguasai ilmu nahwu dan shorof

Peneliti dapat menyimpulkan bahwa belajar nahwu / shorof menjadi pondasi dasar untuk menguasai kitab kuning. Tidak paham itu, maka sulit untuk memahaminya.

Peran Kyai dalam membina akhlak santri di Pondok Pesantren Darul Ulum AlMuinah secara umum telah menunjukan perubahan yang baik terutama pada aspek akhlak, meskipun belum semua santri dapat menunjukan hal itu. lalu santri-santri yang masih memiliki perilaku yang kurang baik yakni dilatar belakangi karena niat dan keinginannya yang tidak mau belajar, ditambah latar belakang pergaulan anak sebelumnya sudah bobrok sebelum masuk ke Pondok Pesantren namun, orang tuanya tetap memaksakan anaknya untuk tetap masuk ke Pondok Pesantren.

Hasilnya ialah santri mengalami kesulitan untuk mematuhi tata tertib yang dibuat oleh pihak Pondok Pesantren, maka dari itu, hal yang sangat penting sebelum menyerahkan anak didik ke Pondok Pesantren, harus ditanyakan kembali tentang keinginan (niat) dari calon santri ini, jangan sampai ditengah perjalanan si calon santri malah meminta berhenti mondok dikarenakan tidak ada kemauan dalam dirinya pribadi. Sudah jelas ini menjadikan kerugian bagi dirinya dan orangtua santri tersebut.

Meskipun demikian, ada pula yang dipaksa untuk Pondok Pesantren dan berujung sukses karena melihat perjuangan orangtuanya mencari nafkah dan tidak mau mengecewakan mereka. Oleh karena itu, niat dan latar belakang santri menjadi hal yang sangat penting sebelum melangkah ke Pondok Pesantren. Niat untuk mondok haruslah benar-benar matang, diiringi dengan keikhlasan dari santri dan ridho orangtua agar kelak menjadi santri yang sukses.

Langkah-langkah yang dilakukan oleh Kyai dalam membina akhlak ialah:

a) Sesepuh mendalami terlebih dahulu karakter dan perilaku santri yang bermukim. Setiap santri memiliki 
karakter yang berbeda, hal ini dipengaruhi oleh latar belakang santri sebelum masuk Pondok Pesantren.

b) Peraturan yang telah dibuat.

c) Apabila santri sudah melebihi batas, sulit untuk dibina dan dididik, maka Kyai berinisiatif mengembalikan kepada orangtuanya. Itu terjadi karena santri tersebut telah terjun dalam pergaulan bebas sebelum masuk Pondok Pesantren.

Setiap program yang dilaksanakan pastinya ada hambatan dan dukungan begitu juga dengan program yang dilaksanakan di Pondok Pesantren Darul Ulum Al-Muinah. Oleh sebab itu, Kyai memiliki cara untuk mengatasi hal tersebut. Masalah yang dihadapi Kyai diselesaikan dengan beberap hal, yaitu:

a) Bermusyawarah dengan para pengurus di Pondok Pesantren;

b) Melakukan umpan balik (feed back)

c) Menganalisis permasalahan atau hambatan yang sedang terjadi;

d) Menentukan solusi dari setiap hambatan yang terjadi;

e) Mengimplementasikan solusi tersebut dilapangan.

Tahapan diatas dilaksanakan oleh pimpinan guna mempermudah menyelesaikan setiap masalah yang terjadi di Pondok Pesantren tersebut. Setiap datangnya hambatan pimpinan tidak langsung memutuskan sebuah kebijakan, akan tetapi selalu bermusyawarah terlebih dahulu dengan para pengurus yang ada di Pondok Pesantren.

\section{KESIMPULAN}

Pelaksanaan pembinaan akhlak di Pondok Pesantren Darul Ulum Al-Muinah yakni Kyai dibantu oleh putra-putri Kyai dan santri lama yang sudah dianggap kompeten dari keilmuwannya. Lalu, dikelompokan menjadi dua bagian yakni santri baru dan santri lama. Santri baru diajarkan oleh santri lama sedangkan santri lama diajarkan langsung oleh Kyai.

Hasil pembinaan akhlak di Pondok Pesantren tersebut yakni: a. Secara umum Pondok Pesantren Darul Ulum Al-Muinah telah menunjukan perubahan yang baik terutama akhlak santri yang bisa terbentuk meskipun belum semua santri dapat menunjukan hal tersebut. Adapun santri-santri yang masih memiliki perilaku yang jelek yakni dilatar belakangi kehidupan pergaulan bebas seelum masuk Pondok Pesantren, alhasil beberapa santri sulit untuk mematuhi aturan/tata tertib yang dibuat oleh pihak Pondok Pesantren.

b. Hendaknya calon santri mempunyai kemauan dan niat yang baik sebelum diserahkan ke Pondok Pesantren, jangan sampai ditengah perjalanan si calon santri murung, yang lebih ironi meninggalkan Pondok Pesantren tanpa sepengetahuan pondok di karenakan tidak ada kemauan dalam dirinya pribadi.

c. Sistem yang digunakan di Pondok Pesantren Darul Ulum Al-Muinah masih terbilang sederhana. Kultur tradisional masih kental yang dintandai dengan pola kehidupoan sederhana dan dilatih untuk menghadapi semua keadaan tanpa berkeluh-kesah.

\section{Daftar Pustaka}

Aim Abdulkarim. Pendidikan

Kewarganegaraan "Membangun Warga

Negara Yang Demokratis," n.d.

Edi Susanto. "Kepemimpinan (Kharismatik)

Kyai Dalam Perspektif Masyarakat

Madura." Karsa 1 (n.d.): 33.

Firman Ariyana. "Peran Kyai Dalam

Membina Akhlak Santri Di Pondok

Pesantren Walisongo Kotabumi

Lampung.” IAIN Raden Intan Lampung, 2017.

Masitoh, Siti, Sofia Gussevi, and Imam

Tabroni. "Peran Wanita Karir Dalam

Pendidikan Anak." Paedagogie: Jurnal

Pendidikan dan studi Islam 2, no. 02

(2021): 109-123. http://e-

jurnal.staimuttaqien.ac.id/index.php/paed agogie/article/view/131. 
Saiful Akhyar Lubis. Konseling Islam Kyai Dan Pondok Pesantren. Yogyakarta: eLSAQ Press, 2007.

Soekanto. Patologi Sosial. Jakarta: Rineka Cipta, 1986.

Syamli, and Firdaus. "Startegi Kyai Dalam Pembinaan Dan Pembentukan Moral Santri Di Ma'had Tahfidz Al-Qur'an Zainul Ibad Prenduan." JPIK 1 (2018): 34.

Tabroni, Imam. MODEL PENDIDIKAN ISLAM: Teknik Mendidik Anak Dengan Treatment Di Era 4.0. Bandung: CV Cendekia Press, 2019.

Thomas Lickona. Educating for Character: How Our Schools Can Teach Respect and Responsibility. New York, Canada: Bantam Books, 1991. 